Tomasz Węcławowicz

ORCID: https://orcid.org/0000-0001-5216-5331

Krakowska Akademia im. Andrzeja Frycza Modrzewskiego

Wydział Architektury i Sztuk Pięknych

\title{
Doświadczanie Krakowa: Stanisława Ignacego Witkiewicza Nienasycenie i Jedyne wyjście*
}

\section{Experiencing of Krakow: Stanislaw Ignacy Witkiewicz's novels Insatiability and The Only Way Out*}

\begin{abstract}
The paper discusses the picture of Krakow in the early 1920s in the surrealist interpretation of Stanislaw Ignacy Witkiewicz, a writer and a painter, as presented in his novels Insatiability and The Only Way Out. However, Witkiewicz did not describe the realities of the city, but a phantasmagorical images of places with which he was associated. The novel's characters are a distorted mirror of his Krakow friends and lovers. Among them he also placed himself, or rather various aspects of his personality.
\end{abstract}

Key words: Krakow, surrealistic novel, autobiographical places

W artykule omówiono Kraków początku lat dwudziestych minionego stulecia w surrealistycznej interpretacji Stanisława Ignacego Witkiewicza przedstawionej w jego powieściach Nienasycenie i Jedyne wyjście. Jednakże Witkiewicz nie opisywał realiów miasta, lecz je fantasmagoryzował, wybierając szczególne

\footnotetext{
" NiniejszyartykułzostałzrealizowanywramachwewnętrznegograntuKAAFMDS/WAiSP/12/2019-2020 pt. Mityzacja architektury Krakowa w wybranych powieściach awangardowych lat międzywojennych XX wieku.

The current article was prepared within the framework of the internal grant KAAFM DS/WAiSP/ 12/2019-2020 entitled Mityzacja architektury Krakowa w wybranych powieściach awangardowych lat międzywojennych XX wieku [Mythicisation of Cracow's architecture in selected avant-garde novels of the 20th-century interwar period].
} 
miejsca, z którymi był związany. Powieściowe postaci są odbiciem w krzywym zwierciadle jego krakowskich przyjaciół i kochanek. Pomiędzy nimi umieścił też siebie, czy też raczej rozmaite aspekty swej osobowości.

Słowa kluczowe: Kraków, powieść surrealistyczna, miejsca autobiograficzne

Odebrano / Received: 15.02.2021

Zaakceptowano / Accepted: 05.10.2021

Ktębowisko zwane Witkacym jest niebezpieczne i trzeba co chwila bronić się przed pokusami,

które podsuwa.

Konstanty Puzyna ${ }^{1}$

Czytając przed laty powieści Witkacego Nienasycenie i Jedyne wyjście, zafascynował mnie Kraków widziany oczyma autora. Nie mogłem oprzeć się pokusie analizy wykreowanych fantasmagorii i szukania ich przyczyn. Było to tym bardziej zajmujące, gdyż niemal wszyscy dotychczasowi badacze nie zwrócili na to uwagi, a może świadomie obronili się przed takimi pokusami. To Witkacy zaprosił mnie na poniższy spacer po swoim Krakowie lat dwudziestych minionego stulecia.

$$
* * *
$$

Kraków fascynował od dawna. Pochwały Krakowa zapisywano w pieśniach i prozą począwszy od Laus Cracoviae Stanisława Ciołka do Boya-Żeleńskiego, a w istocie aż do współczesności (Sinko 1939; Markiewicz 1968). Mityzacja miasta była najczęściej pozytywna, ale czasem i negatywna. Już Balzac nazwał w swoim czasie Kraków „trupem stolicy”, a w czasach nam bliższych, u schyłku wieku XIX Adolfowi Dygasińskiemu miasto jawiło się jako „olbrzymi trup z diademem wawelskim na czole i Mariackim kościołem na piersi” (Grodziska 2003: 7, 100).

Krakowska rzeczywistość - lepsza i gorsza - była bowiem warunkowana wielorakimi okolicznościami. Autonomia galicyjska sprawiła, iż prowincjonalny Kraków końca XIX wieku mógł śnić swój młodopolski sen (Podraza-Kwiatkowska 1973) jako skarbnicy przeszłości, jako „matecznik Polski” (Purchla 1992), jako „scena narodowego teatru” (Kantor 1994). Tu pielęgnowano i rozwijano wartości artystyczne, odwołujące się do dawnej świetności. Ukazywał to zarówno Matejko, jak i nawet Stanisław Przybyszewski. Tu przecież działał nieprzerwanie jedyny w Polsce rozbiorowej Uniwersytet, tu powstała Akademia Umiejętności. Ten stan utrzymał się nawet po I wojnie światowej, kiedy prymat polityczny, a zwłaszcza kulturowy, gwałtownie przejmowały Warszawa i Lwów.

\footnotetext{
1 Motto według Degler 2000.
} 
Można zaryzykować twierdzenie, że sen Krakowa stał się wtedy bardziej głęboki niż w dekadach fin de siècle’u. Kraków międzywojenny był „ideową stolicą Polaków w odwrocie" (Godula-Węcławowicz 2012: 141, 153-154).

Witkacego powszechnie łączy się z Zakopanem i z Warszawą. W Zakopanem miał dom rodzinny i tam też spędzał najwięcej czasu. W Warszawie bywał w latach trzydziestych. Przyjaźnił się z Brunonem Schulzem, Witoldem Gombrowiczem, Zofią Nałkowską. W Warszawie, w roku 1935 został odznaczony Złotym Wawrzynem Akademickim Polskiej Akademii Literatury. W Warszawie zamieszkała po separacji jego żona Jadwiga, którą często odwiedzał, i w Warszawie mieszkała także jego stała partnerka, Czesława Oknińska. Natomiast wcześniejsze, krakowskie epizody życiowe Witkacego z początku lat dwudziestych ubiegłego stulecia jawią się zwykle jako poniekąd drugoplanowe. Ze względów twórczych i życiowych były jednak istotne dla ówcześnie trzydziestokilkuletniego i nadwrażliwego artysty.

Witkacy przebywał w Krakowie wielokrotnie i dobrze poznał miasto. Od roku 1905 w czasie studiów w Akademii Sztuk Pięknych mieszkał na ulicy Topolowej, później na Radziwiłłowskiej i na Pańskiej, czyli dzisiejszej ulicy Marii Curie-Skłodowskiej (Sztaba 2015). Były to okolice bliskie zarówno Akademii, jak i kolejowego dworca; dojeżdżał przecież z Zakopanego. Później, kiedy był kochankiem Ireny Solskiej mieszkał blisko Rynku, na ulicy Grodzkiej (Sztaba 2015). W latach wojny polsko-bolszewickiej służył w garnizonie krakowskim². Wtedy właśnie, we wczesnych latach dwudziestych mieszkał „u Boyów”, czyli u Tadeusza Boya-Żeleńskiego i jego żony Zofii z Pareńskich przy ulicy Krupniczej $13^{3}$. Nota bene Zofia, to owa Zosia z Wesela Wyspiańskiego, niewinne dziecko. Po latach stała się heroiną salonów Krakowa, a Witkacy jej kochankiem (Winklowa 2001: 86).

$\mathrm{Na}$ krakowskiej mapie mentalnej były wtedy określone strefy: lepsze i gorsze. Salonem miasta był Rynek, a raczej tylko jego dwie północne pierzeje: od Hotelu Drezdeńskiego do cukierni Maurizia, czyli tzw. linia AB oraz od pałacu „Pod Krzysztofory" do pałacu Potockich. Snobistyczną dzielnicą była III dzielnica katastralna zwana Nowym Światem. Rozciągała się od brzegów Wisły pod Wawelem do ulicy

\footnotetext{
231 lipca 1920 roku Witkacy stawił się przed komisją lekarską w Komendzie Uzupełnień w Krakowie, a 4 sierpnia przed kolejną komisją, które orzekły o jego nieprzydatności na froncie. Został zatem skierowany na kurs szkoleniowy do Centralnej Szkoły Instrukcyjnej dla Dowództwa Okręgu Generalnego w Krakowie. Tłumaczył wykłady prowadzone przez oficerów francuskich. Po ukończeniu kursu pozostawiono go w szkole jako stałego tłumacza. Wtedy zamieszkał na ul. Krupniczej u Żeleńskich. Dnia 29 grudnia 1920 roku otrzymał przydział w stopniu porucznika do V Zapasowego Baonu Wojsk Wartowniczych i Etapowych w Krakowie-Podgórzu, lecz po dwóch tygodniach, na prośbę jego matki, generał Sosnkowski ostatecznie zwolnił Witkacego z wojska. Por.: Degler 2009: 508-511; Kronika 2017: 288-292.

3 Numer zmieniony później na 11a, Omijanie pechowej 13-tki spotyka się do dziś w numeracji kamienic w Krakowie. W latach międzywojennych na przykład przy ul. Władysława Syrokomli.
} 
Krupniczej. Z końcem XIX wieku zabudowana została okazałymi kamienicami, a nawet pałacami. Najważniejszą ulicą była Wolska, prowadząca od gmachu uniwersytetu na zachód, z widocznym w odległej perspektywie Kopcem Kościuszki ${ }^{4}$. Ważna była też ulica Retoryka, nazwana tak od dawnej jurydyki, należącej do uniwersyteckiej Katedry Retoryki o średniowiecznym jeszcze rodowodzie. Ulica Retoryka obejmowała dwa brzegi niewielkiej rzeczki Rudawy, z czasem zasypanej, była więc poniekąd eleganckim, zadrzewionym bulwarem, choć niewielkim. Opodal, w górnym biegu Rudawy stały opuszczone młyny. Pozostała po nich nazwa ulicy Dolnych Młynów przebiegającej od ulicy Krupniczej w stronę podmiejskiej Czarnej Wsi.

Znacznie gorzej postrzegane były robotnicze okolice na obrzeżach żydowskiego Kazimierza, na przykład w miejscu dawnego folwarku Dajwór. Specyficzną enklawą było też przedmieście zwane Dębniki. W istocie znajdowało się blisko centrum, tuż obok Wawelu, tyle że na przeciwległym brzegu Wisły. Mentalnie było poza Krakowem i sprawiało wrażenie sennego, prowincjonalnego miasteczka.

Te właśnie miejsca, konkretnie określone: ulice Retoryka, Dajwór, Dolnych Młynów oraz przedmieście Dębniki, pojawiają się w powieściach Stanisława Ignacego Witkiewicza Nienasycenie, pisanej z końcem lat dwudziestych, i Jedyne wyjście, pisanej dekadę później i niedokończonej ${ }^{5}$. Autor wybrał je nieprzypadkowo, były bowiem związane $\mathrm{z}$ istotnymi epizodami jego życia.

W Nienasyceniu wzmiankowane są również miejscowości w najbliższych okolicach Krakowa - Kocmyrzów ${ }^{6}$ i Pychowice ${ }^{7}$. W czasach austriackich Kocmyrzów był wsią graniczną, bowiem, na północny wschód od Krakowa, przebiegała rozbiorowa granica między Galicją a tzw. Kongresówką. Można było dostać się tam koleją łączącą sieć koszar, składów amunicji i fortów rozbudowywanych wokół Krakowa w drugiej połowie XIX wieku, kiedy to miasto przekształcano w twierdzę, jedną z największych w Europie Środkowej ${ }^{8}$. Natomiast wieś Pychowice, położona na zachód od Krakowa, nad brzegiem Wisły, na niewysokim wzgórzu, w latach międzywojennych była jeszcze dobrze widoczna spod Wawelu.

Wymieniane są też miejsca sfantasmagoryzowane. Bohater Nienasycenia walczy na ulicy Figlasów Michalika (Witkiewicz 1982: 340). Andrzej Kijowski sugeruje, choć nie wprost, iż może chodzić tu o Cukiernię Michalika zwaną później Jamą Michalika, która

\footnotetext{
${ }^{4}$ Dziś ulica Marszałka Józefa Piłsudskiego.

5 Nienasycenie wydał Witkacy w roku 1930, zresztą nie w Krakowie, ale w Warszawie. Kilka kolejnych wydań ukazało się w latach 1957-2019. Przytaczane poniżej cytaty pochodzą z wydania z roku 1982, sygnowanego przez Państwowy Instytut Wydawniczy. Jedyne wyjście wydano po raz pierwszy w 1968 roku, także przez Państwowy Instytut Wydawniczy.

6 Dziś stolica gminy Kocmyrzów-Luborzyca na północ od Nowej Huty.

7 Dziś jest to willowa dzielnica Krakowa.

8 Zbudowana w 1899 roku linia kolejowa Kraków-Kocmyrzów była w latach międzywojennych linią ćwiczebną i poligonem 1.Pułku Saperów Kolejowych (Batalion Mostów Kolejowycb: 05.02.2021)
} 
jak wiadomo znajduje się w Krakowie przy ulicy Floriańskiej (Kijowski 1960: 48). Figlasami nazywano wtedy ozdobne słodkie wypieki ${ }^{9}$. Niedaleko miał być „półokrągły” plac Dziemborowskiego z „niezbyt wspaniałymi kamienicami” i „małym skwerkiem pośrodku placu" (Witkiewicz 1982: 334,335,336). Tego miejsca nie udało się zidentyfikować. Nota bene autor pisze, iż „nikt nie wiedział na pewno, kto to był ten Dziemborowski”, a „był to nieznany, wielki człowiek tego miasta i okolicznych przysiółków” (Witkiewicz 1982: 334, 338).

Jesienią, w roku 1922 poznał w Zakopanem Jadwigę Unrug, siostrzenicę Wojciecha Kossaka. W następnym roku, w lutym, oświadczył się jej, a w kwietniu ożenił (Degler 2005: 392-417, passim). Między oświadczynami a ślubem narzeczeni przebywali w Krakowie ${ }^{10}$ - Jadwiga u wuja, a Witkacy chwilowo jeszcze „u Boyów”, na Krupniczej, mimo że Zofię bardzo zabolała wiadomość o ślubnych zamiarach kochanka i wkrótce wyrzuciła go z domu (Winklowa 2001: 86; Degler 2005:405). Zatem najpewniej właśnie wczesną wiosną 1923 roku Witkacy chadzał z ulicy Krupniczej do tzw. Kossakówki, rodzinnego domu Juliusza, Wojciecha i Jerzego Kossaków, gdzie czasowo mieszkała Jadwiga. Po drodze mijał ogromny stary młyn przy rogu Krupniczej i ulicy Dolnych Młynów. Idąc dalej, musiał przekroczyć wspomnianą ulicę Wolską i przejść całą ulicę Retoryka. W kolejnych latach, już po ślubie z Jadwigą, także sporadycznie odwiedzał Kossakówkę. Czasem obrażał się, ale zawsze powracał. Miał nawet nieudany romans ze starszą z córek, Lilką ${ }^{11}$. Ostatecznie zerwał stosunki z Kossakami w roku 1932 (Jurgała-Jureczka 2019: 127-131).

Kossakówka, czyli willa rodziny Kossaków z pracowniami malarskimi Juliusza, Wojciecha i Jerzego stała na końcu ulicy Retoryka, niedaleko dawnej rogatki miejskiej. Była miejscem spotkań elit krakowskich od schyłku XIX wieku aż do drugiej wojny światowej. Na drugim końcu ulica Retoryka łączyła się ulicą Wolską. Przy niej wzniesiono reprezentacyjne pałace, kolejno: hrabiów Ogińskich i Potulickich z portykiem kolumnowym na wyniesionym podjeździe ${ }^{12}$, dalej pałac hrabiów Czapskich $^{13}$.Jeszcze dalej stoi kamienica rodziny Janczewskich, zwana Sienkiewiczowską, gdyż pisarz, powinowaty właścicieli, często tu przebywał, a według rodzinnej legendy to tutaj, na piętrze,

\footnotetext{
${ }_{9}$ Potrawy regionalne: 05.02.2021, cyt. Ćwierczakiewiczowa 1885; Stownik Jezyka Polskiego: figlas: 05.02.2021; Brückner 1927: 121.

${ }^{10}$ W marcu 1923 roku Witkacy zdążył jeszcze wziąć udział w skandalizującej wystawie „Niezależnych” w Towarzystwie Rolniczym na pl. Szczepańskim (Kronika 2017: 322-323).

${ }_{11}$ Maria Pawlikowska-Jasnorzewska.

${ }^{12} \mathrm{Nr}$ 4, wybudowany w latach 1874-1879 według projektu Leandro Marconiego przy współudziale Filipa Pokutyńskiego i Zygmunta Hendla, dziś (po nadbudowie z lat 60. XX wieku) siedziba Wyższego Seminarium Duchownego Archidiecezji Krakowskiej (Zabytki 2007: 98).

${ }^{13} \mathrm{Nr}$ 10/12, budowany etapami w latach 1883-1896 według projektów Antoniego Siedeka, Tadeusza Stryjeńskiego i Zygmunta Hendla, dziś Oddział Muzeum Narodowego im. Emeryka Hutten-Czapskiego (Zabytki 2007: 98).
} 
powstała powieść Quo vadis. Natomiast w salonie na parterze gościli Ignacy Paderewski, Helena Modrzejewska i malarz Adam Chmielowski, lepiej znany jako Brat Albert ${ }^{14}$. Po tej samej stronie, w bardzo zaniedbanej obecnie i dostępnej tylko od podwórza kamienicy było mieszkanie rodziny Pugetów - baronów i rzeźbiarzy, a w ogrodzie pracownia rzeźbiarska ${ }^{15}$. Na rogu, na skrzyżowaniu z ulicą Retoryka, stoi pałac Ostaszewskich ${ }^{16}$. Niemal vis à vis miała swą kamienicę Olga Boznańska z pracownią malarską na podda$\mathrm{szu}^{17}$ - upamiętnia to spiżowa tablica przy bramie wejściowej. Opodal na rogu ulicy Wenecja mieszkał i malował Piotr Stachiewicz ${ }^{18}$. Jeszcze dalej, po lewej, stoi kamienica hrabiów Małachowskich z mozaikowym kartuszem herbowym nad portalem ${ }^{19}$, a na samym końcu ulicy dom własny Władysława Ekielskiego, architekta, który wraz ze Stanisławem Wyspiańskim opracował słynny projekt wawelskiej Akropolis $^{20}$.

Pomiędzy tymi artystyczno-arystokratycznymi krańcami - Kossakówką i ul. Wolską - rozciągała się owa ulica Retoryka, a przy niej stały kamienice - zwyczajne i niezwyczajne. U schyłku XIX wieku kilka $\mathrm{z}$ nich zaprojektował $\mathrm{i}$ zrealizował Teodor Talowski - zgodnie uważany za jednego z najważniejszych polskich architektów tego czasu. W historii polskiej architektury zasłynął projektem monumentalnego kościoła św. Elżbiety we Lwowie i właśnie kamienicami przy krakowskiej ulicy Retoryka. Domy te należą do stylistyki późnego historyzmu, ale bardzo indywidualnie interpretowanego. Detale elewacji są malowniczą kompilacją elementów architektonicznych renesansu, manieryzmu i wątków ceglanych stylizowanych na gotyckie. Pierzeja ulicy Retoryka zdecydowanie odróżniała się od innych ulic Krakowa.

Na rogu Wolskiej stoi kamienica „Pod Śpiewającą Żabą”, o elewacji będącej parafrazą manieryzmu niderlandzkiego, gdzie jasny, piaskowcowy kamień kontrastuje ze spieczoną ciemną cegłą. W niszy nad pierwotnym gzymsem umieszczona jest rzeźba

${ }^{14} \mathrm{Nr}$ 16, wybudowany w 1890 roku według projektu Władysława Kaczmarskiego i Sławomira Odrzywolskiego, dziś hotel Akademii Górniczo-Hutniczej (Zabytki 2007: 273).

${ }^{15} \mathrm{Nr}$ 18, dzieło Tadeusza Stryjeńskiego z 1890 roku. Wpisany do Rejestru Zabytków (Zabytki 2007: 274), zruderowany dom stoi w głębi podwórza. Jan Puget-Puszet, krytyk teatralny i literacki, eseista i tłumacz mieszkał tam do śmierci w 1993 roku, bezskutecznie walcząc o utworzenie rodzinnego muzeum. Natomiast na początku lat 60. XX wieku na terenie dawnej posiadłości Pugetów, wzdłuż dawnej ul. Wolskiej zbudowano długi budynek biurowo-mieszkalny (dziś marszałka Józefa Piłsudskiego 18-22).

${ }^{16} \mathrm{Nr}$ 24, wzniesiony w 1895 roku według projektu Józefa Pokutyńskiego, dziś „Hotel Ostoya” (Zabytki 2007: 98).

${ }^{17} \mathrm{Nr}$ 21, dom Boznańskich, wzniesiony 1867, z pracownią malarską na poddaszu (Zabytki 2007: 274; Kuźniak 2019, passim).

${ }^{18}$ U1. Wenecja 1, tzw. Dom Wenecki, zwany też Domem pod Św. Markiem, wzniesiony w latach 1911-1912 według projektu Kazimierza Hroboniego, ozdobiony tablicą pamiątkową z płaskorzeźbionym portretem Piotra Stachiewicza (Zabytki 2007: 355).

${ }^{19} \mathrm{Nr} 36$, kamienica wzniesiona w latach 1907-1908 według projektu Władysława Ekielskiego (Zabytki 2007: 274).

${ }^{20} \mathrm{Nr}$ 40, wzniesiony w 1899 roku według projektu Władysława Ekielskiego (Zabytki 2007: 274). 
żaby grającej na mandolinie ${ }^{21}$. Następna kamienica w tej pierzei, o bardziej tradycyjnej fasadzie, zwraca uwagę wyniosłym, historyzującym szczytem, niemal niderlandzkim ${ }^{22}$. Natomiast kolejna jest jakby dla kontrastu zupełnie zwyczajna, chociaż także jest dziełem Talowskiego ${ }^{23}$. Domem własnym Talowskiego była kamienica zwana Festina lente. Fasada jest tu asymetryczna, zbudowana z różnych materiałów. Znajdują się na niej inskrypcje: Festina lente (Spiesz się powoli) i Ars longa vita brevis (Sztuka trwa długo, życie jest krótkie) oraz nazwisko architekta w dekoracyjnym obramieniu ${ }^{24}$.

$Z$ kolei jeszcze następna nazywana jest „Pod Oślą Głową”. Na narożu wykusza znajduje się bowiem pełnoplastyczny łeb osła, który nawiązuje do inskrypcji, nawołującej do upartego dążenia do celu - Faber est suae quisque fortunae (Każdy jest kowalem swojego losu $)^{25}$. Nieco dalej, już za skrzyżowaniem z ulicą Smoleńsk stoi jeszcze jedna kamienica, o skromnej, typowej, historyzującej fasadzie, ale z inskrypcją: Dtugo myśl, prędko czyñ ${ }^{26}$, a naprzeciw, po drugiej stronie ulicy na wydłużonej parceli pod nr 10 i 12 stał „Dom Egipski”. Nie był to projekt Talowskiego, lecz znanego krakowskiego budowniczego Beniamina Torbe. „Dom Egipski” zawdzięczał swą nazwę dekoracji z motywami egipskimi: kwiatami lotosu, uskrzydlonymi słonecznymi dyskami, a największe wrażenie robiły siedzące ponad portalem dwie pełnoplastyczne figury Izydy i Faraona ${ }^{27}$.

Analizę twórczości Talowskiego przeprowadzano wielokrotnie ${ }^{28}$. Nie będzie więc tutaj referowana. Jednakże nie postawiono istotnych pytań: dla kogo owe domy były projektowane, kto zamawiał i akceptował te nietypowe projekty i kto wprowadzał się do

${ }^{21}$ U1. Retoryka 1, kamienica wzniesiona w latach 1889-1890 (Zabytki 2007: 288). Zwykle mówi się, że owa żaba nawiązuje do rechotu żab, jaki było słychać w okolicy, poniewaź środkiem ulicy leniwie płynęła Rudawa. Inna hipoteza głosi, że w budynku mieściła się szkoła muzyczna. W trakcie konferencji poświęconej Teodorowi Talowskiemu, zorganizowanej przez dr Annę Jasińską w Collegium Maius UJ, w październiku 2013, Tadeusz Bystrzak wyjaśnił, że szkoła muzyczna funkcjonowała tam krótko i dopiero w latach międzywojennych, ale już w projekcie parter kamienicy z narożnym podcieniem był przeznaczony na restaurację. Tadeusz Bystrzak rozszyfrował też nuty i słowa popularnej ówcześnie biesiadnej piosenki, które są zapisane na banderoli na fasadzie.

${ }^{22}$ U1. Retoryka 3, kamienica wzniesiona w latach 1891-1893 (Zabytki 2007: 288).

${ }^{23}$ Ul. Retoryka 5, kamienica wzniesiona w latach 1887-1888 (Zabytki 2007: 288).

${ }^{24}$ Ul. Retoryka 7, kamienica wzniesiona w 1887 roku (Zabytki 2007: 288).

${ }_{25}$ Ul. Retoryka 9, kamienica wzniesiona w 1891 roku (Zabytki 2007: 288).

${ }^{26}$ Ul. Retoryka 15, kamienica wzniesiona w 1888 roku (Zabytki 2007: 289).

${ }^{27}$ Wzniesiona w latach 1889-1890. Na jednym z rysunków projektowych widnieje podpis „K. Lachnik”. Beniamin Torbe jest jednak określony jako budowniczy (Fischer, Zinkow 2004: 33-57; Zinkow 2009: 173) lub „projektant” (Zabytki 2007: 288). Dom stoi do dziś, ale jego elewacja jest zasadniczo zmieniona, w roku 1929 elewację zmodernizowano w stylistyce art déco. Projektantami byli Mieczysław i Włodzimierz Gruszczyńscy (Węcławowicz 2020: 108, 114-115). Uskrzydlone dyski słoneczne pozostały jedynie na stolarce bram wjazdowych, a figury faraonów dożywają swych dni w kącie podwórza pod schodami kuchennej klatki schodowej.

${ }^{28}$ Najważniejsze opracowania: Beiersdorf 1973; Sepioł 1977; Bałus 1988; Bałus 1994; Sołtysik 2012; Bystrzak 2017. 
domów „Pod Śpiewającą Żabą” czy „Pod Oślą Głową”. Rezultaty kwerendy okazały się zaskakujące. Właścicielami i lokatorami opisanych kamienic nie byli ani architekci, ani malarze, ani literaci, ani nawet tzw. ludzie kultury krakowskiego fin de siècle. Słowem, żadnej cyganerii - sami kupcy, lekarze, adwokaci ${ }^{29}$. Nasuwa się zatem wniosek, że owi zacni mieszczanie, wprowadzając się do ekscentrycznych domów przy ulicy Retoryka chcieli zapewne zaistnieć w blasku mieszkającej w pobliżu arystokracji i artystów, zwłaszcza,że malarska twórczośćJuliusza i Wojciecha Kossaków oraz Piotra Stachiewicza była bezpieczna, bo bardzo zachowawcza i w prowincjonalnym, mieszczańskim Krakowie aprobowana $z$ wielką atencją. Natomiast malarstwo Olgi Boznańskiej, mającej też swoje pracownie w Monachium i w Paryżu, spełniało wszelkie lokalne wyobrażenia o europejskiej awangardzie.

Jednakże prawdziwa awangarda rodziła się właśnie w Krakowie. Już w latach pierwszej wojny działali „Formiści, czyli polscy ekspresjoniści” (Jakimowicz 1989; Kostyrko 2006; Geron 2012; Geron 2015). Witkacy brał udział w pierwszej ich wystawie w Krakowie w 1917 roku i kilku następnych ${ }^{30}$. Proponował też swoje dramaty do Teatru Miejskiego i publikował teksty teoretyczne. Formiści próbowali naśladować przede wszystkim kubistyczną geometryzację. W obrazach Witkacego widać ekspresjonistyczną abstrakcję koloru, ale także nadrealną przestrzeń. Chociaż nie mógł znać jeszcze Manifestu surrealizmu sformułowanego i wydanego przez André Bretona dopiero w roku 1924 (Breton 1924; Janicka 1985; Taborska 2007), to spełniał wszystkie jego warunki, albowiem tworzył i żył w sposób surrealistyczny (Janicka 1972: 245-255).

Niestety eksperymenty formistów skończyły się ledwie po kilku latach. W Krakowie początku lat dwudziestych awangardowe obrazy nie były zrozumiałe, a nawet nie wywołały większego skandalu. Również sztuki teatralne Witkacego nie zostały zaakceptowane przez elitę miasta ${ }^{31}$.Jest zatem zupełnie zrozumiałe, że okiem awangardowego artysty,

${ }^{29}$ Kwerenda została przeprowadzona w: Józefa Czecha Kalendarz Krakowski 1887-1913: passim; Wielka księga adresowa 1907: passim; Wielka ksiegga adresowa 1925: passim; Spis abonentów 1925, passim. Udało się ustalić, iż obie kamienice pod nr 1 i 3 posiadali Sylwester i Helena Rychterowie, którzy odsprzedali kamienicę nr 3 bliżej nieznanym Wincentemu i Stanisławie Janoszom. Kamienica nr 5 była własnością Talowskiego, który tu mieszkał przez długi czas wraz z żoną. Kamienica nr 9 należała do przybyłej ze Lwowa kupieckiej rodziny Stadtmüllerów. Karol Stadtmüller był inżynierem, autorem pierwszego polskiego słownika technicznego. „Dom Egipski” początkowo kilkakrotnie zmieniał właścicieli, nawet w trakcie budowy. Inwestorem miał być Józef Kulesza, a pierwszym właścicielem Joel Bauminger, jednak dom należał także (może część) do doktora Leona Horowitza, adwokata, a potem do jego córki, która wyszła za mąż za Zygmunta Wachtela, lekarza. Jeszcze później cały dom stał się własnością doktora Józefa Ostoi Zagórskiego, a po 1905 roku - „Funduszu stypendyjnego” jego imienia (Fischer, Zinkow 2004: 42-43).

${ }^{30}$ „I Wystawa Ekspresjonistów” w Pałacu Sztuki w Krakowie została otwarta 4 listopada 1917 roku, a Witkacy został oficjalnie przyjęty do formistów w jesieni 1918 (Kronika 2017: 270).

${ }^{31}$ M.in. przez Tadeusza Peipera, w przeciwieństwie np. do wystaw we Lwowie i dramatów tam wystawianych (Kronika 2017: 298-363, passim). 
krytycznie oceniał on krakowski, spóźniony fin de siècle. Sfrustrowany opuścił Formistów i zaprzestał malowania obrazów olejnych ${ }^{32}$. Wyprowadził się do Zakopanego i ożenił. Wkrótce jednak rozstał się z żoną, która na stałe zamieszkała w Warszawie. Nic więc dziwnego, że miasto i jego mieszkańcy, a w szczególności okolice ulicy Retoryka nie kojarzyły mu się pozytywnie. Założył „Firmę portretową”, z której się utrzymywał i poświęcił się pisaniu powieści oraz sztuk teatralnych. W jego literackiej twórczości „demon surrealistyczny” jest tak samo czytelny, jak i w malarskiej. Bohaterów obu powieści, będących zwykle alter ego autora, otaczają demoniczne postaci, najczęściej kobiety. Przy tym, w toku narracji jedności czasu i miejsca urywają się, przeplatając się z filozoficznymi rozważaniami i ,informacjami” wstawianymi niczym didaskalia.

Po wyjeździe z Krakowa Witkacy zaczął pisać Nienasycenie, w której to powieści konsekwentnie pomijał nazwę miasta lub szyfrował ją, pisząc: „regionalna stolica K, w skrócie RSK” (Witkiewicz 1982: 194), „zagwazdrane miasto K” (Witkiewicz 1982: 312), „ta dziura K” (Witkiewicz 1982: 312). Natomiast kilkanaście razy literalnie wymienił dobrze mu znaną ulicę Retoryka, czasem ironizując - „ulica św. Retoryka”. Pojawia się ona $\mathrm{w}$ tekście powieści po raz pierwszy zaledwie kilka wersów przed ową „Regionalną Stolicą K” z określeniem „każdy wie, gdzie to jest” (Witkiewicz 1982: 194) ${ }^{33}$. Wkrótce zaczął Jedyne wyjście, pisane długo i niedokończone, gdzie nazwa Krakowa w ogóle się nie pojawia, nawet w inicjale, ale rozpoznajemy krakowskie miejsca akcji w nazwach ulic Dajwór i Dolnych Młynów oraz przedmieścia Dębniki.

Literackie fantasmagorie Witkacego na temat Krakowa były rezultatem rozczarowania miastem. Zresztą chyba generalnie nie lubił tego miasta, gdzie w listopadowej błotnistej aurze „zamarza materia w mózgu i myśli kręcą się w kółko bez wyjścia” ${ }^{34}$.

32 Ostatecznie „Formiści” rozpadli się w marcu 1922 roku, ale Witkacy już kilka miesięcy wcześniej nosił się z zamiarem wystąpienia $\mathrm{z}$ tej grupy artystycznej (Kronika 2017: 312-313, przypis 99).

${ }^{33}$ Drugoplanowym bohaterem jest tu niejaki Sturfan Abnol. „Postanowił [on] wychować [narzeczoną] na swoją żonę nowego typu (...). Mieszkali w czterech pokoikach w opuszczonym pałacu Gąsiorowskich na ulicy Retoryka” - i jak pisze dalej Witkacy - „każdy wie, gdzie to jest” (Witkiewicz 1982: 194). Jedyny „pałac” przy ul. Retoryka to wspomniany wyżej pałacyk Ostaszewskich (ul. Wolska 24) o skromnej neoklasycznej architekturze, ale jego wyposażenie było zapewne imponujące. Do dziś zachowały się polichromie na plafonach. Natomiast wspomniany wyżej monumentalny „Dom Egipski” (ul. Retoryka 10-12) istotnie w latach 20 . był zaniedbany i być może nawet częściowo opuszczony, zanim jego elewacje nie zostały przemodelowane w roku 1929 (por wyżej przyp. 28). Kluczem do lokalizacji może tu być nazwisko Gąsiorowskich. Witkacy znał rodzinę generała Janusza Tadeusza Gąsiorowskiego (Witkiewicz 2015: II, 227, 503). Być może również znał Stanisława Jana Gąsiorowskiego, późniejszego profesora archeologii UJ, a w latach 20. młodego asystenta, który właśnie wrócił z frontu wojny polsko-bolszewickiej. W powieściach Witkacego zwykle każda postać jest parodią rzeczywistych osób z kręgu jego znajomych, ale nie zawsze łatwo rozszyfrować ich realną tożsamość.

${ }^{34}$ W liście do Kazimiery Żuławskiej w roku 1919 (Kronika 2017: 282). 
Znaczące jest to, że w swych krakowskich fantasmagoriach Witkacy używa toponimii realnej, ale szczególnej. Dla czytelnika poza-krakowskiego wydaje się być ona jakimś surrealistycznym kodem i taki był zapewne cel autora. Pojawia się zatem pytanie: dla kogo obie książki była przeznaczone, kto miał rozszyfrować te mało znane zakątki Krakowa i komu miały przywoływać wspomnienia - żonie Jadwidze, Lilce Kossakównie, Zofii Stryjeńskiej, czy też przyjaciołom formistom z Leonem Chwistkiem na czele? Literaturoznawcy, zarówno krakowscy jak i spoza Krakowa, nie konfrontowali tych fantasmagorycznych miejsc akcji powieściowych z realiami miasta. Nawet autorzy wstępów i posłowia do Nienasycenia - Czesław Miłosz (Witkiewicz 1977: VII-XXII) i Michał Misiorny (Witkiewicz 1982: 418-428) - oraz do Jedynego wyjscia - Tomasz Jodełka-Burzecki (Witkiewicz 1968: 244-253) także nie podjęli tych wątków ${ }^{35}$.

Aby uniknąć nadinterpretacji ostrożność badawcza zwykle nakazuje rozdzielać wątki osobiste autora od powieściowych, ale przy wnikliwej analizie krakowskie miejsca powieściowe odpowiadają realnym krakowskim miejscom doświadczanym przez Witkacego. Wątki osobiste w powieściach Witkacego są tym bardziej zrozumiałe, iż pomimo małżeńskiej separacji przesyłał żonie do Warszawy wszystkie teksty, a rękopis pierwszej części Jedynego wyjścia jej zadedykował (Kronika 2017: 465). W Nienasyceniu ulica Retoryka wymieniona jest co najmniej kilkanaście razy i jak było wspomniane, jej pierzeje z pretensjonalną architekturą mogły być tłem jego spacerów do Kossakówki. Natomiast Kocmyrzów był celem jego przejazdów wojskowych, a Pychowice zapewne celem spacerów $\mathrm{z}$ Jadwigą. Trudniej rozszyfrować podobne, osobiste tropy w Jedynym wyjściu, być może dlatego, że jest to powieść niedokończona.

Krakowskie miejsca autora i ich doświadczanie ujawniają się czytelnie w wielowątkowym, rozbudowanym i pełnym dygresji Nienasyceniu. W istocie ujawnia się tam sam Witkacy, albowiem parafrazując znane słowa Jana Błońskiego, treść powieści „rozjaśnia się łatwo, jeżeli przyjąć, że bohaterami poruszają te same potrzeby, co pisarzem” (Błoński 1970, Puzyna 1999: 55 i n).

Główny bohater - alter ego autora - nazywa się Genezyp Kapen, czyli ledwo zipiący. Tym francusko-polskim makaronizmem [Je ne „zipe” que peu] autor posługiwał się już wcześniej w roku 1919, podpisując wstęp do swej pierwszej powieści 622 upadki Bunga, czyli Kobieta demoniczna (Witkiewicz 1972: 48), a dwa lata później tekst w „Gazecie

\footnotetext{
${ }_{35}$ Tym bardziej profesor Daniel C. Gerould, Amerykanin, badacz i tłumacz literatury polskiej, nie rozpoznał w „regionalnej stolicy K” Krakowa, pisze bowiem, iż „pierwsza połowa powieści [Nienasycenia] kończy się wyjazdem młodego bohatera do stolicy" (Gerould 1981: 391, 393). Niewtajemniczony czytelnik może przypuszczać, że chodzi o Warszawę. Natomiast warszawianka, dr Floryńska-Lalewicz z Instytutu Filozofii i Socjologii PAN, nie rozpoznaje krakowskich toponimów: Dajwór, Dębniki, Dolnych Młynów, i jednoznacznie umieszcza akcję pierwszej części Jedynego wyjścia w Warszawie. Pisze bowiem, iż w drugiej, nienapisanej części powieści autor miał przenieść bohaterów „Z Warszawy do Zakopanego” (Floryńska-Lalewicz 2004).
} 
Zakopiańskiej”36. Poza tym wszystkie powieściowe nazwiska i imiona są u Witkacego znaczące, chociaż nieraz zaszyfrowane $w$ akronimach i neologizmach. Niemal każde imię i nazwisko jest albo anagramem prawdziwego nazwiska, albo neologizmem, kontaminacją słów, zwykle francuskich, niemieckich lub angielskich. Niemal - bo nie wszystkie udaje się rozszyfrować.

Fantomy opisywanego w Nienasyceniu świata poznajemy w działaniach powieściowych postaci. Witkacy patrzy na swój wyobrażeniowy Kraków oczyma głównego bohatera, a zarazem komentuje jego poczynania i stany emocjonalne. Genezyp, dorastający młodzieniec, wkracza „na salony” skupiające szalonych artystów i nienasycone kobiety. Przechodzi kolejne erotyczno-metafizyczne wtajemniczenia - od Przebudzenia (tytuł pierwszej części powieści) do Obtędu (tytuł części drugiej). Przy tym równolegle z sekwencją powolnych upadków bohatera upadał jego świat, bezpieczny i znany, albowiem do granic Polski powoli zbliżała się bezwzględna armia chińska. Losy Genezypa i wydarzenia wojenne są wiodące $\mathrm{w}$ toku całej narracji i wzajemnie się przeplatają. W tych dramatycznych okolicznościach Genezyp zostaje powołany na „przyspieszony kurs oficerski do Szkoły Wyszkolenia Wojennego”(Witkiewicz 1982: 185) w owej „Regionalnej Stolicy <K>" (Witkiewicz 1982: 187, 194), czyli - jak uważam - w Krakowie. Tutaj obiektem jego uczucia zostaje perwersyjna i demoniczna Persy Zwierżątkowskaja ${ }^{37}$, „pó1 Polka, pół Rosjanka, praprawnuczka słynnego Zwierżątkowskiego spod Somo-Sierry" (Witkiewicz 1982:187), a równocześnie kochanka niejakiego Erazma Kocmołuchowicza, "generał-kwatermistrza”.

Właśnie na ulicy Retoryka umieścił Witkacy mieszkanie Persy. Bohater Nienasycenia Genezyp Kapen, niczym Witkacy w czasach narzeczeńskich,

po całodziennych ćwiczeniach za miastem (...) popędził (...) koło szóstej na ulicę Retoryka do Persy. (...) Mieszkała tam drętwa, sama z jakąś kucharo-dueniq (...). Przyjęła go w łóżku, wśród jakichś piór à la Wrubel (ten malarz, nie ptaszek), hiper-brabanckich przezroczystości i poduszek, których poduszkowatość przechodziła sen o lenistwach najwschodniejszego $\mathrm{z}$ książąt ziemi. Wszystko to było bardzo tanie, tylko skonstruowane z niesłychanie sadystycznym smaczkiem (...) Zaledwie niemiła duenia postawiła przybory do herbaty i wyszła (uśmiechając się przy tym tak, jakby chciała powiedzieć: $\mathrm{O}$ wiem

\footnotetext{
${ }^{36}$ Tym razem znaczenie tego pseudonimu wyjaśnił w przypisie do tekstu owego artykułu: „Genezyp Kapen = Genezipe Quapêne = Je ne zipe qu'a peine = ledwo zipię. A jednak zipię całą parą i będę zipieć aż do śmierci" (Kronika 2017: 297).

${ }^{37}$ Imię jej, jak zwykle u Witkacego, jest znaczące, używane jako angielski kolokwializm/wulgaryzm. Zatem w wolnym tłumaczeniu imię i nazwisko można rozumieć jako „Seksualne Zwierzątko”, którym - jak wynika z treści książki - w istocie była. Nie odważę się postawić tezy, że to alter illa, jednej z kobiet autora, chociaż pewną przesłanką może być wyjątkowy kolor włosów. Postać Persy pojawia się już wcześniej w sztuce Witkacego pt. Persy Zwierżątkowskaja, wystawionej w Łodzi w roku 1927 (Degler 1967). Niestety tekst tej sztuki zaginął.
} 
dobrze, co tu będzie za chwilę), Persy odkryła kołdrę koloru róży herbacianej i zawinęła koszulę pod szyję (Witkiewicz 1982: 294-295).

Dekadencja i nikłe blaski minionego fin de siècle - taki był krakowski świat ulicy Retoryka w wyobrażeniach pisarza. U schyłku wieku XIX był to rzeczywiście jeden z salonów mieszczańskiego Krakowa - specyficzny, bo łączący w sobie pieniądze i sztukę, ale sztukę mieszczańską, dobrą warsztatowo i zacną tematycznie. Natomiast w czasach Witkacego, czyli krótko po pierwszej wojnie, ulica Retoryka była miejscem granicznym w rzeczywistej przestrzeni: tu kończyło się miasto a zaczynały rozlegle łąki - tzw. Błonia i tzw. Półwsie Zwierzynieckie ${ }^{38}$.

Przez czarną czeluść otwartego okna dolatywał mokry zapach świeżo skoszonych łąk (...) gdzieś szczekał pies i na tle tego szczekania bzykała raz po raz mucha. (...) W tej dziurze $\mathrm{K}$ wszystko było blisko. Co chwila utykało się nosem w przedmieściach, a właśnie ulica Retoryka była na samej „opuszce” ${ }^{\text {39 }}$ miasta - jak z wdziękiem mówiła Persy (Witkiewicz 1982: 312).

W wymiarze społecznym graniczna ulica Retoryka łączyła w sobie bogate mieszczaństwo, artystów i arystokrację. W metaforze temporalnej na ulicy Retoryka dogorywał mieszczański świat Krakowa i ów krakowski, młodopolski sen. Natomiast podróże Genezypa z kwatermistrzem Kocmołuchowiczem koleją wojskową do Kocmyrzowa to ślad realnych służbowych przejazdów kadeta-porucznika Witkiewicza ${ }^{40}$. W lecie 1920 roku został powołany do V Baonu Wojsk Wartowniczych i Etapowych stacjonującego w Krakowie-Podgórzu (Degler 2009:508-511).Tam też pojawia się bohater Nienasycenia. Wracając ze spotkania z siostrą

puścił się biegiem w kierunku niedalekiej szkoły [wojskowej]. Za dwie i pół minuty zobaczył między domami piętrzący się na wapiennych skałach ponury gmach. (...) Biegł bez tchu schodami kutymi w skale (Witkiewicz 1982: 330).

${ }^{38}$ Wielohektarowa łąka tzw. Błoń (48 ha) jest zachowana do dziś i wpisana do Rejestru Zabytków, a Półwsie Zwierzynieckie jest współczesną dzielnicą willową. Obie strefy - miasto i Błonia z Półwsiem - rozdzielone były wtedy linią kolejową, choć z rzadka używaną. Dzisiejsza aleja Zygmunta Krasińskiego wytyczona została w tym miejscu i zabudowana dopiero w latach trzydziestych.

39 „Opuszka” to intrygujące i wieloznaczne określenie okolicy jako miejsca wrażliwego i „końcowego”, a zarazem zamierzony przez autora rusycyzm, który włożył w usta Persy, jako że miała ona (podobnie jak Witkacy) skłonność do rusycyzmów.

${ }^{40}$ Linia kolejowa z Krakowa do Kocmyrzowa prowadziła przez przedmieście Grzegórzki, a dalej przez ówczesne podkrakowskie wsie: Dąbie, Czyżyny, Bieńczyce, gdzie były tereny wojskowych ćwiczeń i wojskowe magazyny. Była obsługiwana przez I Pułk Saperów, do którego Witkacy został na krótko przydzielony. 
Istotnie, koszary wojskowe w Podgórzu mieściły się wtedy w pobliżu skał wapiennych tzw. Krzemionek Podgórskich ${ }^{41}$.

Natomiast Pychowice, gdzie rozgrywa się dramat upadku kraju i scena finalna Nienasycenia, czyli egzekucja Kocmołuchowicza, były być może miejscem nadwiślańskich spacerów narzeczonych Stanisława Ignacego i Jadwigi. Scena egzekucji rozgrywa się przed dworkiem, który do dziś tam się tam znajduje ${ }^{42}$. Autor nie bez powodu nazywa go „dworem starokonstantynowskim”. Starokonstantynów leży daleko od Krakowa, na dzisiejszej Ukrainie, w pobliżu Płoskirowa (Chmielnickiego), na historycznym tzw. Czarnym Szlaku, którym zagony tatarskie zapuszczały się w głąb Rzeczypospolitej, a w 1920 roku szarżowała Konarmia Siemiona Budionnego. Nic dziwnego, że podobną drogą maszerują powieściowi „Chińczycy”. Istotne jest jednak, iż w okolicy Starokonstantynowa, w Mokijówce, leżały dobra ziemskie rodziny żony Witkacego Jadwigi Unrug, utracone bezpowrotnie po rewolucji bolszewickiej ${ }^{43}$. Można powiedzieć, że realia historyczne i treści osobiste zostały tu poniekąd „sfantasmagoryzowane" ${ }^{\text {. }}$.

W kolejnej powieści Jedyne wyjście Witkacy ulokował dom bohaterów na przedmieściu Dębniki, które znajdują się naprzeciw Wawelu, po drugiej stronie Wisły i na pewno widać je było wtedy z okien Kossakówki. Tamtędy można było dojść do przywołanych w Nienasyceniu Pychowic. Witkacy musiał zatem „po drodze” przechodzić przez Dębniki i poznać ich prowincjonalny charakter. Główny bohater Jedynego wyjścia, Izydor Smogorzewicz Wędziejewski, zamieszkał tam w wynajętych pokojach z poślubioną Rustalką Ideyko (Witkiewicz 1968: 53-54). Podobnie jak Genezyp Kapen z Nienasycenia

\footnotetext{
${ }^{41}$ Były to nieistniejące już dziś Koszary Jagiellonów (ul. Kalwaryjska) i Koszary Grunwaldzkie (ul. Wielicka). Ponadto na szczycie wzgórza Krzemionek stały: Fort 31 św. Benedykta i Fort 32 Krzemionki. Oba o trzech kondygnacjach, z małymi dziedzińcami pośrodku, przystosowano wtedy do funkcji koszarowych. Przy Kopcu Krakusa, także ponad kamieniołomem, stał Fort 33 Krakus i koszary. Fort 33 rozebrano częściowo w 1933 roku, ostatecznie w 1954 roku. Fort 32 rozebrano w roku 1954, a opuszczony Fort 31 zachował się w całości (Holewiński 1998). Z cytowanego wyżej opisu w Nienasyceniu można przypuszczać, że Witkacy miał w pamięci Fort 32 lub 33, które stały ponad skałami dawnych kamieniołomów. Później, do 15 stycznia 1921 roku, porucznik Witkiewicz służył krótko w Koszarach Króla Sobieskiego przy ul. Warszawskiej 24 (Porucznik Witkacy 2011).

${ }^{42}$ Dziś własność prywatna. Nie udało się ustalić, kto tam mieszkał na początku lat dwudziestych XX wieku.

${ }^{43} \mathrm{~W}$ wielu opracowaniach Mokijówka jest błędnie lokalizowana na Podolu (np. Witkiewiczowa Jadwiga, 05.02.2021). Jedynie Janusz Degler prawidłowo zlokalizował ją w parafii starokonstantynowskiej na Wołyniu (na południowowschodnich rubieżach Wołynia), chociaż nie zwrócił uwagi na wzmiankowany w Nienasyceniu „dwór starokonstantynowski” (Degler 2005: 413). Po pokoju ryskim w 1923 roku okolice Starokonstantynowa znalazły się w granicach Związku Sowieckiego i Mokijówka została po prostu zgładzona niczym jeden z bohaterów Nienasycenia, Erazm Kocmołuchowicz, zdekapitowany przed „starokonstantynowskim dworem" - jak to opisuje Witkacy (Witkiewicz 1982: 408-415).

${ }^{44}$ Daniel C. Gerould nie zwraca uwagi na określenie „starokonstantynowski”. Dla niego akcja dzieje się po prostu przed „starym polskim dworem” (Gerould 1981: 414-416).
} 
to również w dużym stopniu alter ego autora ${ }^{45}$. Tworzył nowy system filozoficzny ${ }^{46}$, upajał się seksem i narkotykami. Polemizował z Leonem Chwistkiem, Bertrandem Russelem i Rudolfem Carnapem, tak właśnie jak Witkacy w swoich ówczesnych pismach. Postanowił się ożenić i owa „oficjalna miłość” u boku Rustalki, kobiety nieskomplikowanej, przepełniła go spokojem i szczęściem. Poczciwa Rustalka początkowo speszona brakiem dziewictwa była też zaborcza, skoro dzięki instytucji małżeństwa otrzymała Izydora „na własność” (Witkiewicz 1968: 56, 58, 60.). Podziwiała go i chciała, aby ją uczył (Witkiewicz 1968: 71). Była też dumna. Pochodziła bowiem ze sławnego litewskiego rodu. Kniaź Olgierd miał rozkazać jej przodkowi: „Idź i zwycięż”, i tak powstało nazwisko Ideyko (Witkiewicz 1968: 7.). Jest to autoironia, jedna z licznych, spotykanych w wielu tekstach autora, albowiem Witkiewiczowie herbu Nieczuja to rodzina litewska ${ }^{47}$. Jednakże może to być też przytyk do rodziny żony, von Unrugów, starego rodu śląskiego wymienianego w Almanachu Gotajskim ${ }^{48}$.

W Jedynym wyjściu Izydor i Rustalka spacerują brzegiem Wisły, podziwiając zachód słońca „nad kopcem”, czyli przekładając na podkrakowskie realia topograficzne, idą z Dębnik w kierunku Pychowic, patrząc na Kopiec Kościuszki, tak - jak domyślamy się - spacerował Witkacy z Jadwigą w okresie narzeczeńskim.

Inne krakowskie miejsca wymieniane w przywołanej powieści to stary młyn na ulicy Dolnych Młynów, w którym mieszkał przyjaciel Izydora, Marceli (Witkiewicz 1968: 116-117), oraz ulica Dajwór (Witkiewicz 1968: 137), gdzie mieszkała jego kochanka o wielce znaczącym nazwisku Suffretka Nunberg ${ }^{49}$. Młyn ów był całkowicie realny, pokaźny, murowany i aż do schyłku lat trzydziestych stał na rogu ulicy Krupniczej i Dolnych Młynów. Po zasypaniu tzw. młynówki rzeczki Rudawy około 1915 roku, był bezużyteczny i opuszczony. Witkacy, mieszkając u Żeleńskich na ul. Krupniczej, niemal widział go z okna, a na pewno wielokrotnie przechodził obok, kierując się do ulicy Retoryka. Powieściowy, demoniczny Marceli miał tam pracownię malarską. Był twórcą „wściekle” awangardowym, więc należy go traktować również jako alter ego autora ${ }^{50}$.

${ }^{45}$ O osobistym charakterze Jedynego wyjścia świadczy fakt, że kiedy w roku 1933 Witkacy ukończył pierwszą część pt. Przyjaciele, to zadedykował ją swej żonie.

${ }^{46}$ Rozprawę Izydora pt. Ontologia ogólna, nowym sposobem wytożona można rozumieć jako przywołanie traktatu autora (Witkiewicz 1935).

${ }^{47}$ Witkiewiczowie byli nawet spowinowaceni z Piłsudskimi przez Billewiczów. Zob. Bajor 2009; Witkiewicz 2015: I, 308 przypis 22. Litewskie legendy Witkacy wykpiwał już wcześniej w swoim dramacie Janulka córka Fizdejki pisanym w 1923 roku. Natomiast w Nienasyceniu wzmiankowani są hrabiowie Chraposkrzeccy mający w swoim herbie „żabi skrzek i końską chrapę”(Witkiewicz 1982: 137).

${ }^{48}$ Przed spolonizowaniem w 1919 roku nazwisko brzmiało von Unruh (co w wolnym thumaczeniu znaczy „niespokojny”). Nota bene Witkacy był przekornie bardzo dumny z pochodzenia swej narzeczonej. (Jurgała-Jureczka 2015: 121).

${ }^{49}$ Najpewniej od fr. suffire - wystarczać, być wystarczającym, być dla kogoś wszystkim oraz od niem. nun tylko i berg - wzgórze, czyli w wolnym tłumaczeniu „dająca wystarczającą satysfakcję tylko wzgórkiem”. Wzmianki o Suffretce (Witkiewicz 1968: 137-224 passim).

${ }^{50}$ Niedziałkowska 2009: 369-387 interpretuje Marcelego jako „fikcyjne przedłużenie życia autora” por:: Skwara 2012: 119, przypis 281. Nota bene zarówno historycy sztuki, jak i literaturoznawcy nie zadają sobie 
Suffretka Nunberg, „rozkosznawa ponad zwykłą miarę” (Witkiewicz 1968: 144), mieszkała - jak czytamy w powieści - „na Dajworze”. Znaczące jest, iż Witkacy używa tego lokalnego kolokwializmu, bo mieszkać „na Dajworze” znaczy przy ulicy Dajwór, która wzięła nazwę od dawnego folwarku. Nawet współcześnie jest to okolica zaniedbana, a jeszcze niedawno była enklawą ruder i starych warsztatów. Tak samo, a nawet gorzej, wyglądała w czasach Witkacego, ale dla niego zapewne fascynująco. Znał ją dobrze, gdyż w stojącej w pobliżu, zachowanej do dziś willi, w latach 1916-1923 mieszkali Karol i Zofia Stryjeńscy, z którymi początkowo był zaprzyjaźniony, lecz później, w roku 1925, miał z Karolem „sprawę honorową” o kobietę

Jan Błoński podkreślał, iż

wszystkie dziedziny twórczości Witkiewicza były raczej równoległe niż od siebie pochodne czy sobie podporządkowane. Ale (...) literatura - gdzie na pewno sięgnął najwyżej - wyraża też Witkiewicza najpełniej, obejmuje z Witkacego najwięcej. Więc jeśli już, to raczej ona objaśnia (czy pomaga zrozumieć) estetykę, filozofię, malarstwo, projekt życia ... nie odwrotnie [...] Dziwna monada, której na nazwisko Witkiewicz - Witkacy, była jednak zwierzęciem przede wszystkim literackim (Błoński 1997: 125).

Literatura krytyczna literackiej twórczości Witkacego dotyczy przede wszystkim dramatów, a spośród powieści najwięcej uwagi poświęcono 622 upadkom Bunga i Pożegnaniu jesieni, których akcja rozgrywa się w Zakopanem. Są wcześniejsze od Nienasycenia i odmienne w konstrukcji. Jednakże omówienia, analizy, a niekiedy tylko wzmianki i dygresje o Nienasyceniu są względnie częste, natomiast o Jedynym wyjściu znacznie rzadsze ${ }^{52}$. Literaturoznawcy, zarówno krakowscy jak i spoza Krakowa, skupiali się przede wszystkim na konstrukcji powieści, surrealistycznych zabiegach artystycznych oraz na demonicznych kobietach. Nie stawiali dotychczas pytań dotyczących powieściowych realiów: o powód i cel zamiany miejsc akcji z Zakopanego w dwóch pierwszych powieściach na Kraków w dwóch kolejnych. Nie zwracano uwagi, iż w Nienasyceniu pod

pytań: gdzie Witkacy malował swoje formistyczne obrazy w czasie pobytu w Krakowie? U Boyów na Krupniczej? A może obok, w jednym z pomieszczeń owego młyna. Później, już po latach pisania Jedynego wyjścia, młyn został rozebrany. Dziś w tym miejscu jest skwer i parking przed sąsiednim szpitalem im. Józefa Dietla.

${ }^{51}$ Dawna willa Stryjeńskich przy ul. Starowiślnej 89 (zaprojektowana przez Tadeusza Stryjeńskiego) jest dziś niestety bardzo zruderowana. Do jej tylnej ściany, właśnie od ulicy Dajwór (nr 18), przylegały niewielkie piętrowe hale wykorzystywane przez kilka lat, do 1926 roku, przez „Warsztaty Krakowskie” (później, po roku 1931, fabryka maszyn „Molitor”). Dla Zofii Stryjeńskiej Witkacy wykonał nawet ex libris, reprodukcja w: Degler 2009: 140, il. 52; Natomiast o „sprawie honorowej” por. Degler 2006; Witkiewicz 2015: I, 294, 296-299; II, 461-462.

${ }^{52}$ Najważniejsze pozycje podano w załączonej bibliografii. 
inicjałami „K” i „RSK” został zaszyfrowany Kraków53, a tym bardziej, dlaczego w Krakowie tak ważne dla autora okazały się: ulice Retoryka i Dajwór, przedmieście Dębniki, wsie Kocmyrzów i Pychowice oraz odległy, kresowy Starokonstantynów, no i dlaczego jeden z bohaterów miał pracownię malarską w jakimś „starym młynie” przy ul. Dolnych Młynów.

Jak było powiedziane, Witkacy dobrze poznał Kraków jeszcze w okresie studiów w Akademii Sztuk Pięknych. Na początku lat 20. już ukształtowany i wrażliwy trzydziestopięciolatek intensywnie doświadczał miasto, towarzysko i artystycznie, a zarazem sam został „doświadczony” przez Kraków. Klasyczne sposoby doświadczania miasta opisał sześćdziesiąt lat temu Kevin Lynch ${ }^{54}$. Doświadczający miasto formują jego mentalną mapę w oparciu o pięć elementów: path, edges, districts, nodes, landmarks, które dla niniejszej analizy można przetłumaczyć jako: ulice, ich pierzeje, dzielnice, miejsca spotkań, architektoniczne dominanty. Przy tym według Lyncha, pewne miasta mają szczególne predyspozycje do wywoływania wzruszeń u doświadczających je mieszkańców. Bliskie temu są również bardziej współczesne spostrzeżenia Władimira Toporowa, iż czytanie „tekstu miejskiego” polega na przemianach realiów materialnych w wartości duchowe, albowiem struktura materialna miasta inspiruje artystów - malarzy, pisarzy, poetów (Toporow 2000: 49-50).

Natomiast niedawno Małgorzata Czermińska trafnie zaproponowała

wyróżnienie kategorii miejsca autobiograficznego dla badania zjawisk sytuujących się na pograniczu literatury i geografii (...) zetknięciu biografii pisarza i jego twórczość (...). [Jednakże] Aby miejsce autobiograficzne mogło zaistnieć, konieczne są dwa warunki: element autobiograficzny $\mathrm{w}$ twórczości autora oraz wyobraźnia wrażliwa na realia (..) Elementy konstytuujące miejsce autobiograficzne mogą być skupione w jednym utworze, zasadniczo poświęconym tematowi lokalizacji w przestrzeni, bywają też rozproszone po różnych tekstach, sukcesywnie uzupełniających lub przekształcających wizję miejsca. Mimo możliwej literackiej wielokształtności, odnosi się ono zawsze do toponimicznie określonego terytorium, znanego z biografii pisarza. Do tego terytorium czytelnik może mieć swój własny dostęp, niezależny od wizji stworzonej przez danego pisarza, ponieważ istnieje ono pozawerbalnie, jako obiekt geograficzny, wyposażony we właściwą sobie kulturową symbolikę (Czermińska 2011: 183, 185).

Istotnie, owe miejsca powieściowe i biograficzne pojawiają się zarówno w Nienasyceniu, jak i w Jedynym wyjściu, pisanych kolejno w krótkim czasie; koncepcje tworzył niemal równolegle ${ }^{55}$. Miejsca te istnieją realnie w Krakowie i czytelnik może je weryfikować współcześnie lub na archiwalnych fotografiach.

\footnotetext{
53 Por. przypis 35.

${ }^{54}$ Lynch 1960

${ }^{55}$ Witkacy pisał Nienasycenie od czerwca 1927 do grudnia 1929 roku, a pierwszą cześć Jedynego wyjścia od kwietnia 1930 do września 1933 roku (Kronika 2017: 384, 391,392, 414, 415, 418, 429, 450, 460, 465).
} 
Czermińska podkreśla ponadto, iż

[miejsce autobiograficzne] związane jest zawsze $\mathrm{z}$ topograficznym, materialnym konkretem, nawet jeśli zostaje on poddany przekształceniom literackim, właściwym nie tylko metaforze, możliwej w konwencji realistycznej, ale także prawom oniryzmu i fantastyki (Czermińska 2011: 188).

Owe miejsca autobiograficzne w Nienasyceniu i Jedynym wyjsciu Witkacego to w istocie loci memoriae, swoista mapa wspomnień z jego pobytu w Krakowie. Wpisują się w spostrzeżenia Elżbiety Rybickiej, analizującej Dykcjonarz wileńskich ulic Czesława Miłosza i nazywająca ten gatunek auto/bio/geo/grafią (Miłosz 2006: rozdz. I; Rybicka 2013). Zwraca ona przy tym uwagę, że „ważne są nie tyle pytania o <prawdę> reprezentacji miejsc geograficznych, czy o <prawdę> auto/biografii (...) Kluczową rolę w takim typie wypowiedzi z perspektywy geopoetyki odgrywać będą interakcje pomiędzy przestrzenią geograficzną, doświadczającym podmiotem oraz twórczością pojmowaną jako poiesis" (Rybicka 2013:16-17, 23). Istotnie, topografia Krakowa i okolic przytoczona we wspomnianych powieściach jest nieco zaburzona, zaszyfrowana, nie zawsze czytelna, a przede wszystkim wybiórcza. Witkacy pomija bowiem ulice, przy których rzeczywiście mieszkał, ale kreuje „miejsca” wyobrażeniowej biografii swoich alter ego: Genezypa, Izydora i Marcelego. Fantazyjne elewacje kamienic przy ulicy Retoryka, dobrze widoczne $\mathrm{z}$ dystansu szerokiego bulwaru, stały się scenografią, gdzie rozgrywała się akcja Nienasycenia. Podobnie zostały potraktowane w Jedynym wyjściu przedmiejskie Dębniki, rudery ulicy Dajwór i ów stary młyn na ulicy Dolnych Młynów.

Daniel C. Gerould trafnie spostrzegł, iż Witkacy nie opisuje realiów, ale ich oddziaływanie, jakie wywołują. Dzięki temu autor może oddać to, co przeżywa sam patrząc oczami powieściowego bohatera - swego alter ego (Gerould 1981: 394-395). Związek przyczynowo-skutkowy między owymi Witkacowskimi miejscami a mieszkającymi tam wykreowanymi kuriozalnymi postaciami Witkacowskich bohaterów jest ścisły i jednoznaczny.

Powieściowa topopoetyka krakowskich miejsc - ulic Dajwór i Retoryka, przedmieścia Dębniki - była metonimią groteski miasta. Literackie fantasmagorie to retrospektywa pobytu autora w Krakowie. W istocie obie powieści są autobiograficzne, lecz zaszyfrowane. Taka narracja jest narzędziem,jedynym właściwym dla pisarza. Wzmianki o ulicach, przedmieściach, w tym szczególnie liczne o ulicy Retoryka, można rozumieć jako odreagowanie doświadczania tych miejsc przez autora. Za pretensjonalną architektoniczną formą kreował nadrealne treści. Akcja Nienasycenia toczy się w kostiumach jak pisze - à la Michaił Wrubel. Obrazy tego secesyjnego rosyjskiego malarza istotnie epatują niezwykle dekoracyjnym przepychem. Tak sobie pisarz wyobrażał wnętrza „hipebrabanckich”, „poduszkowatych”, lecz „bardzo tanich” mieszczańskich salonów na ulicy Retoryka. Powieściowe postaci są krzywym zwierciadłem jego krakowskich przyjaciół i kochanek. Pomiędzy nimi umieścił też siebie, czy też raczej rozmaite aspekty swej 
osobowości: Genezypa - neurotycznego kochanka, Izydora - filozofa i Marcelego awangardowego malarza.

Rozbicie osobowości autora na dwie postaci - myśliciela i artysty, wzajemne zmagania i dialogi, to $\mathrm{w}$ istocie wewnętrzne dialogi Witkacego. Najpełniej przedstawione zostały w Jedynym wyjściu. W części pierwszej, pod nieco przewrotnym tytułem Przyjaciele, wewnętrzny konflikt narastał. Nasuwają się tu nieodparte skojarzenia z rozterkami, których doświadczał Carl Gustav Jung i opisał je sumarycznie u schyłku życia w autobiografii (Jung 1962: 180-183). Swoje emocje przekładał na malowanie obrazów (Prokopiuk 1976: 8). Podobnie równoległymi drogami - intelektualną i twórczą - kroczył Witkacy ${ }^{56}$. Być może nienapisana (niedokończona?) część druga, z zamierzonym i pozytywnym, jak się wydaje, tytułem Dygnitarze, miała być uspokojeniem wewnętrznych sporów autora.

\section{Bibliografia}

Bajor A.A. 2009. Żmudzko-litewskie konteksty rodziny Witkiewiczów i Matusewiczów. [W]: J. Degler (red.). Witkacy: bliski czy daleki? Materiaty z międzynarodowej konferencji z okazji 70. rocznicy śmierci Stanistawa Ignacego Witkiewicza, Muzeum Pomorza Środkowego 17-19 września 2009. Slupsk: Muzeum Pomorza Środkowego, 419-426.

Bałus W.1988. Historyzm, analogiczność, malowniczość. Rozważania o centralnych kategoriach twórczości Teodora Talowskiego (1857-1910). Folia Historiae Artium 24. 1988, 117-138.

Bałus W.1994.Dom - przybytek - „nastrój dawności”. O kilku kamienicach Teodora Talowskiego, [W:] R. Godula. Klejnoty i sekrety Krakowa. Kraków: Wydawnictwo Wawelskie, 215-238.

Beiersdorf Z. 1973, Architekt Teodor Talowski. Charakterystyka twórczości. [W:] Hrankowska T. (red.). Sztuka 2 potowy XIX wieku. Warszawa: PWN, 199-214.

Błoński J. 1970. U źródeł teatru Witkacego. Dialog 15/ 1970. 5, 81-90.

Błoński J. 1997 Od Stasia do Witkacego. Kraków: Wydawnictwo Literackie.

Błoński J. 2003. Witkacy na zawusze. Kraków: Wydawnictwo Literackie.

Breton A.1924. Manifeste du surréalisme. Poisson soluble. Paris: Éditions du Sagittaire.

Brückner A.1927. Stowniketymologicznyjęzyka polskiego. Kraków: Krakowska SpółkaWydawnicza [przedruk: 1993. Warszawa: Wiedza Powszechna].

Bystrzak T. 2017. Teodor Marian Talowski. Attyka, Kraków: Attyka.

Czapska-Michalik M. 2007. Formiści. Warszawa: Edipresse Polska S.A. [Ludzie-Czasy-Dzieła 40]. Czermińska M. 2011. Miejsca autobiograficzne. Propozycja w ramach geopoetyki. Teksty Drugie 5, 183-200.

Ćwierczakiewiczowa L. 1885. Jedyne przepisy konfitur, różnych marynat, wędlin, wódek, likierów, win owocowych, miodów oraz ciast, Warszawa: nakładem autorki.

${ }^{56}$ Fascynacje Witkacego Jungiem są prawdopodobne, lecz niełatwe do jednoznacznego wykazania. Być może tzw. ogniwami pośrednimi były teksty Kurta Beringera, przyjaciela Junga i Williama Sterna oraz ewentualnie Bertranda Russella (Witkiewicz 2015: II, 103, 393; III: 46, 72, 159, 177; IV: 92, 364). Por. też: Dybel 2020, passim. 
Degler J. 1967. „Persy Zwierżontkowskaja”Stanisława Ignacego Witkiewicza. Prace Literackie IX, 163-191.

Degler J. 2000. Puzyna i ktębowisko zwane Witkacym. https://witkacologia.eu/witkacolodzy/ Puzyna.html 05.02.2021.

Degler J. 2005. Witkacy się żeni, [W:] W. Dynak, M. Ursel (red.). Pejzaże kultury. Prace ofiarowane Profesorowi Jackowi Kolbuszewskiemu w 65. rocznice Jego urodzin. Wrocław: Wyd. Uniwersytetu Wrocławskiego, 392-417.

Degler J. 2006. O „sprawie honorowej” Witkacego z Karolem Stryjeńskim. Przyczynek do biografii. Odra 5, 7-13.

Degler J. 2009. Witkacego portret wielokrotny. Szkice i materiaty do biografi 1918-1939, Warszawa: PIW.

Dybel P. 2020. Nieświadome na scenie. Witkacy i psychoanaliza, Kraków: Universitas.

Fischer I., Zinkow L. 2004. Dom egipski” w Krakowie - przykład egiptomanii w architekturze polskiej. Modus. Prace z Historii Sztuki V, 33-57.

Floryńska-Lalewicz H. 2004. Witkacy - myśliciel i powieściopisarz. https://culture.pl/pl/artykul/ witkacy-mysliciel-i-powiesciopisarz 05.02.2021

Geron M. 2012. Formiści. Pomiędzy tradycją a awangardą. Zabytkoznawstwo i Konserwatorstwo 43, 181-199.

Geron M., 2015. Formiści. Twoórczośc i programy artystyczne, Toruń: UMK.

Gerould D. C. 1981. Stanistaw Ignacy Witkiewicz jako pisarz, Warszawa: PIW.

Godula-Węcławowicz R. 2012. Kraków międzywojenny. Utrata romantycznego mitu miasta.

[W:] B. Soukupová et al. (red.). Mýtus-realitá-identitá. Státni a národni metropole po proni svètové válc., Praha: Univerzita karlova, 141, 153-154 [Urbánni Studie 3].

Grodziska K. 2003, Gdzie miasto zaczarowane. Księga cytatów o Krakowie. Kraków: Znak;

Holewiński M. 1998, Kraków przed stu laty - Szczegótowy plan twierdzy Kraków z roku 1904, Kraków: Towarzystwo Miłośników Historii i Zabytków Krakowa.

Jakimowicz I. 1989. Formiści. Warszawa: Muzeum Narodowe.

Janicka K. 1972. Stanisław Ignacy Witkiewicz a surrealizm. [W:] M.Głowiński, J. Sławiński (red.). Studia o Stanistawie Ignacym Witkiewiczu, Wrocław: Uniwersytet Wrocławski, 245-255 [Z Dziejów Form Artystycznych w Literaturze Polskiej, XXX].

Janicka K. 1985. Światopoglad surrealizmu. Jego zatożenia i konsekwencje dla teorii twórczości i teorii sztuki. Warszawa: Wydawnictwa Artystyczne i Filmowe.

Józefa Czecha Kalendarz Krakowski. 1887-1913. Kraków: nakładem autora.

Jung C. G. 1962. Erinnerungen-Traüme-Gedanken. A Jaffé (red.). Zurich-Stuttgart.

Jurgała-Jureczka J. 2015. Kobiety Kossakóww. Warszawa: PWN.

Kantor R. 1994. Kraków - wielka scena narodowego teatru. [W:] R. Godula (red.). Klejnoty i sekrety Krakowa. Teksty z antropologii miasta. Kraków: Wydawnictwo Wawelskie, 37-62.

Kijowski A. 1960. Samobójstwo przez parodię. Twórczość 9, 40-53.

Kostyrko T. 2006. Formiści polscy a ideologia awangardy. [W:] L. Bieszczad (red.). Wiek awangardy. Kraków: Universitas, 391-405. 
Kronika życia i twórczości Stanistawa Ignacego Witkiewicza, 2017. J. Degler, A. Micińska, et al. (red.). Warszawa: PIW.

Kuźniak A. 2019. Boznañska. Non finito. Kraków: Wydawnictwo Literackie.

Lynch K. 1960. The Image of the City. Cambridge MA and London: The M.I.T.Press.

Markiewicz H. 1968. Boy o Krakowie. Kraków: Wydawnictwo Literackie.

Miłosz C. 2006. Zaczynajac od moich ulic. Kraków: Znak.

Niedziałkowska D. 2009. Autoportrety Stanisława Ignacego Witkiewicza - twarze dandysa. „Wyszlachetnienje podozoritienloj licznosti” kontra „Le vrai visage du maître”. [W:] J. Degler. (red.). Witkacy: bliski czy daleki? Materiaty z międzynarodowej konferencji z okazji 70. rocznicy śmierci Stanistawa Ignacego Witkiewicza, Muzeum Pomorza Środkowego 17-19 września 2009. Słupsk: Muzeum Pomorza Środkowego, 369-387.

Podraza-Kwiatkowska 1973. Somnambule (o młodopolskiej konwencji onirycznej), Teksty: teoria literatury, krytyka, interpretacja 2 (8), 64-79.

Pomian K.1973. Powieść jako wypowiedź filozoficzna. Próba strukturalnej analizy „Nienasycenia”.

[W:] tenże. Cztowiek pośród rzeczy. Szkice historyczno-filozoficzne. Warszawa: Czytelnik, 145-180.

PorucznikWitkacy 2011.https://forum.odkrywca.pl/topic/685094-porucznik-witkacy/05.02.2021. Prokopiuk J. 1976. C. G. Jung, czyli gnoza XX wieku. [W:] Jung C. G. Archetypy i symbole. Pisma wybrane. Warszawa: Czytelnik, 5-56.

Purchla J. 1992. Matecznik Polski. Kraków: Znak.

Puzyna K. 1999. Witkacy. J. Degler (red.). Warszawa: Errata.

Rybicka E. 2013. Auto/bio/geo/grafie. Biatostockie Studia Literaturoznawcze. Studia i Szkice 4, $7-23$.

Sepioł J. 1977. Talowski fecit. Architektura 5-6, 57-60.

Sinko T. 1939. Trzy najdawniejsze pochwały Krakowa. Kurier Literacko-Naukowy 22, I-II;

Skwara M. 2012. Wśód Witkacoidów: W świecie tekstów, w świecie mitów. Wrocław: Uniw. Wrocławski [Dramat-Teatr 27].

Sołtysik A. 2012. Język form Teodora Talowskiego a wspótczesne kompozycja architektoniczna [praca doktorska - Wydział Architektury Politechniki Wrocławskiej], Kraków.

Spis abonentów Pañstwowej Sieci Telefonicznej Okręgu Krakowskiej Dyrekcji Poczt i Telegrafów. Wedtug stanu z dnia 31 grudnia 1924, 1925, Cieszyn (nakładem Henryka Nowaka).

Sztaba W. 2015. Miejsca zwiqzane z pobytem S. I. Witkiewicza w Krakowie. https://witkacologia. eu/Miejsca_Witkacego/Witkacy_w_Krakowie.html, 05.02.2021

Taborska A. 2007. Spiskowcy wyobraźni. Surrealizm, Gdańsk: Słowo-Obraz-Terytoria [seria: Eseje o sztuce].

Tarnowski J. 1996 Witkacy, Fukuyama i koniec historii. [W:] J. Degler. (red.), Witkacy - Życie i twórczość. Materiaty sesji poświęconej Stanistawowi Ignacemu Witkiewiczowi z okazji 55 rocznicy śmierci. Stupsk. Muzeum Pomorza Środkowego 16-18 września 1994, Wrocław: Uniwersytet Wrocławski, 99-120 [seria Wiedza o kulturze];

Toporow W. 2000. Miasto i mit, Gdańsk: Słowo-Obraz-Terytoria. 
Węcławowicz T. 2020. Krytyka pretensjonalnego historyzmu w twórczości Witkacego i Gruszczyńskiego na przykładzie ul. Retoryka w Krakowie. Państwo i Spoteczeństwo Architektura i sztuka 2020 (XX), 3, 101-116.

Wielka księga adresowa Stotecznego Królewskiego miasta Krakowa i Królewskiego Wolnego miasta Podgórza III. 1907. Kraków (nakładem Stefana i Maryi Mikulskich).

Wielka księga adresowa Stotecznego Królewskiego miasta Krakowa i Królewskiego Wolnego miasta Podgórza X. 1925. Kraków (nakładem Stefana i Maryi Mikulskich).

Winklowa B. 2001. Boyowie. Zofia i Tadeusz Żelenssy. Kraków: Wydawnictwo Literackie.

Witkiewicz S I. 1935. Pojecia i twierdzenia implikowane przez pojęcie Istnienia, Warszawa: Kasa Mianowskiego.

Witkiewicz S. I. 1968. Jedyne wyjście. Warszawa: PIW.

Witkiewicz S. I. 1972. 622 upadki Bunga, czyli demoniczna kobieta. Warszawa: PIW.

Witkiewicz S. I. 1977. Insatiability (L. Iribarne tłum.). London-Melbourne-New York: Encounter.

Witkiewicz S. I. 1982. Nienasycenie. Warszawa: PIW.

Witkiewicz S. I. 2015. Listy do żony, I-IV. A. Micińska, J. Degler (oprac.). Warszawa: PIW.

Zabytki architektury i budownictwa w Polsce: Kraków. 2007. Warszawa: Krajowy Ośrodek Badań i Dokumentacji Zabytków.

Zinkow L. 2009 Imhotep i pawie pióra. Z dziejów inspiracji egipskich w architekturze polskiej. Kraków: Księgarnia Akademicka.

\section{Źródła internetowe}

Batalion Mostów Kolejowych: https://pl.wikipedia.org/wiki/1_Batalion_Mostów_Kolejowych, 05.02.2021

Potrawy regionalne: http://potrawyregionalne.p1/193,3123,ROGALE_PALUCHY_OBWARZ ANKI_I_INNE_FIGLASY_htm, 05.02.2021

Stownik Języka Polskiego: figlas: https://sjp.pwn.pl/doroszewski/figlas;5427583.html, 05.02.2021

Witkiewiczowa Jadwiga: https://pl.wikipedia.org/wiki/Jadwiga_Witkiewiczowa, 05.02.2021

Autor:

Prof. dr hab. Tomasz Węcławowicz

U1. Francesco Nullo 16/15, 31-543 Kraków

e-mail: tomasz@weclawowicz.pl 
